\title{
Economics
}

2015; 4(3): 41-49

Published online June 15, 2015 (http://www.sciencepublishinggroup.com/j/eco)

doi: 10.11648/j.eco.20150403.11

ISSN: 2376-659X (Print); ISSN: 2376-6603 (Online)

\section{Exchange Rate Pass-Through in Nigeria}

\author{
Mathias A. Chuba \\ Department of Economics, Faculty of Social Sciences, Kogi State University, Anyigba, Nigeria
}

\section{Email address:}

machuba50@gmail.com

\section{To cite this article:}

Mathias A. Chuba. Exchange Rate Pass-Through in Nigeria. Economics. Vol. 4, No. 3, 2015, pp. 41-49. doi: 10.11648/j.eco.20150403.11

\begin{abstract}
The paper seeks to determine the effect of exchange rate changes on consumer prices in Nigeria using recursive vector autoregression (VAR) model. It uses data from first quarter 2000 to fourth quarter 2013. The results of the investigation show that exchange rate fluctuation has a positive and insignificant effect on consumer prices and the increase in consumer prices are mainly due to its own shocks and the increase in money supply in the long run. A stable monetary policy with a low inflationary environment will lessen the pressure of exchange rate changes on consumer prices. So, the Central Bank of Nigeria should be less concern with the inflation impact of exchange rate shocks and focus fully on other objectives such as growth and export competitiveness in designing exchange rate policy.
\end{abstract}

Keywords: Pass-Through, Exchange Rate, Vector Auto Regression (VAR)

\section{Introduction}

Kahn (1987), Menon (1995), and Goldberg and Knetter (1997) define exchange rate pass-through (ERPT) as the change in domestic prices that can be attributed to a prior change in the nominal exchange rate. Inflation has always been one of the most important macroeconomic issues. Due to this importance, a study concerning the factors associated with the behaviour of inflation is therefore imperative (Achsani, Fauzi and Abdullah, 2010).

The importance of the ERPT has been generally analyzed by various economists. Two identified important roles of the ERPT are the forecasting capacity of inflation and its policy implications on monetary policy (Minh, 2009). Basically, the most important role of the ERPT is its influence in the forecasting capacity of inflation, which is very important for any central bank in conducting monetary policy. Having underpinned with a good assessment of the ERPT, the central bank is able to understand the influence, degree and timing, of any exchange rate shock to change in inflation. Therefore, the central bank, especially one with an inflation targeting regime, can respond in a timely way with proper monetary policy to keep inflation within the targeted area (Minh, 2009).

The level of the ERPT has some implications. First, the level of the ERPT implies the pricing power of foreign exporters. A low level of the ERPT implies that foreign exporters will not choose to adjust the price due to exchange rate shock, while a high level of the ERPT means firm is able to adjust the price in response to exchange rate shock. A quick adjustment of price implies that the firm has a strong pricing power and hesitance in price adjustment means less pricing power. Second, coupled with an inflation forecasting capacity, the level of the ERPT will help the central bank in determining monetary policy. If the assessment reveals that the ERPT is low, the central bank will be less concerned by the inflation impact of exchange rate shocks. As a result, the central bank will focus fully on other objectives such as growth and export competitiveness in designing exchange rate policy as well as monetary policy. In the context of a high level of the ERPT, however, the central bank will have to be more concerned with the inflationary impact of the exchange rate shocks. Large fluctuations of the exchange rate will be translated into inflationary pressure in the economy. It is therefore difficult to conduct a suitable exchange rate policy (Minh, 2009). Therefore, it is important for a country to ascertain the extent of ERPT to understand, design and conduct monetary policy better. Despite its importance, the determination of ERPT has been the most challenging problem in Nigeria. The essence of this study is to determine the effect of exchange rate changes on consumer prices in Nigeria.

The paper consists of seven sections. The next section is literature review. Section 3 presents the research methodology. The results are discussed in section 4 and section 5 concludes. Section 6 gives an account of the strengths and weaknesses of the work and section seven provides suggestions for further studies. 


\section{Literature Review}

McCarthy (1999) analyzed the impact of exchange rates and import prices on domestic producer price index (PPI) and CPI in six industrialized OECD countries using data from 1976:1 to $1998: 4$. He used a recursive VAR framework in his analysis. From the impulse response function and variance decomposition he found that the exchange rate has a modest effect on domestic price over the post-Breton Woods era. Another finding of his paper is that the pass-through is stronger in countries with a large import share.

Mirdala (2014) analyzes exchange rate pass-through to domestic prices in the European transition economies. He estimated VAR model to investigate (1) responsiveness of exchange rate to the exogenous price shock to examine the dynamics (volatility) in the exchange rate leading path followed by the unexpected oil price shock and (2) effect of the unexpected exchange rate shift to domestic price indexes to examine its distribution along the internal pricing chain. To provide more rigorous insight into the problem of exchange rate pass-through to the domestic prices in countries with different exchange rate arrangements he estimates models for two subsequent periods 2000-2007 and 2000-2012. His result suggests that there are different patterns of exchange rate pass-through to domestic prices according to the baseline period as well as the exchange rate regime diversity.

In case of Turkish economy, Leigh and Rossi (2002) consider the time period January 1994-April 2002 and investigate the impact of exchange rate movements on domestic prices using VAR framework. They find that: (1) the impact of the exchange rate on prices is over after about a year, but is mostly felt in the first four months; (2) the pass-through to wholesale prices is more pronounced compared to the pass-through to consumer prices and (3) the estimated pass-through is complete in a shorter time period and is larger than that estimated for other key emerging market countries.

Justel and Sansone (2015) investigate the exchange rate pass-through (ERPT) to different price indices in Chile. The analysis is carried out with vector autoregressive (VAR) model with exogenous variables. Models were estimated using monthly data for Chile from January 1987 to December 2013. Average pass-through ratio to total CPI is estimated to be between 0.1 and 0.2 in the medium term. These results indicate a lower ERPT after the adoption of inflation targeting. Moreover, from 2002 onwards the effect of an exchange rate movement takes around four quarters to pass-through completely compared to one to two years for the full sample.

Chowdhury and Siddique (2006) estimate the extent of exchange rate pass-through to domestic inflation in Bangladesh based on McCarthy's (1999) approach of a recursive VAR model using data from July 1997 to March 2005. They generate impulse-response functions (IRF) to quantify the effect of exchange rate shock on wholesale price index (WPI) and CPI. They also use variance decomposition (VDC) to see the proportion of the movements in a sequence due to its own shock versus shocks to the other variables. The IRFs and VDCs show that exchange rate fluctuation does not have any significant effect on WPI or CPI inflation and the forecast error variances of WPI and CPI inflation are mostly influenced by quantum index of industrial production which is used as a proxy for demand shocks. In case of WPI none of the other variables in the model has any significant impact and over 12 percent of CPI error variance is attributed to WPI inflation.

Mohammed et al (2015) examine the exchange rate pass-through on producer and consumer price indexes in the Algerian economy through an empirical analysis using a vector autoregressive model upon quarterly data for the 2002-2011. The empirical findings show that the consumer price increases in response to an appreciate foreign exchange rates against the Algerian Dinar, while the pass-through of Euro against the Algeria Dinar exchange rate is 'complete' and more increasing in the time horizon compared the pass-through of US dollars/DZ exchange rate. In the contrast the exchange rate pass-through involves a negligible reaction on producer price index (PPI). In the second step of the variance decomposition estimate the magnitude contribution of demand shock to explain CPI and PPI change ranges from $50 \%$ and $17 \%$ after thirty quarterly respectively, whereas supply shock (oil price) continue to contribute largely to CPI fluctuations (30\%) and quite modestly to PPI (5\%).

Frimpong and Adam (2010) examine the effect of exchange rate changes on consumer prices in Ghana using vector auto-regression (VAR) models. They estimated a four-variable VAR(domestic price level, foreign price level, nominal exchange rate and interest rate) using a data set covering the period 1990: Q1-2009:Q2. They find that the exchange rate pass-through to inflation is 'incomplete' and decreasing in Ghana. Their empirical results indicate a low but significant pass-through in the short run. They argued that the findings reflect the impact of increased openness and tighter monetary policy pursue by the central bank over the period.

Fullerton and Ikhide (1998) attempt to provide insights with respect to short - run price dynamics in Nigeria. They used quarterly Nigerian data from first quarter 1970 to fourth quarter 1993. In their first equation, the lagged narrow money supply $\left(\mathrm{M}_{1}\right)$, lagged inflation rate and lagged official exchange rate were regressed on current price level. In their second equation, the lagged broad money supply $\left(\mathrm{M}_{2}\right)$, lagged inflation rate and lagged official exchange rate were regressed on current price level. The exchange rate coefficients are not statistically significant at 5 percent level.

Imimole and Enoma (2011) examined the impact of exchange rate depreciation on inflation in Nigeria for the period 1986-2008, using Auto Regressive Distributed Lag (ARDL) Co-integration Procedure. They regressed one year lagged value of inflation rate, current nominal exchange rate of the naira in terms of US dollar, current nominal broad money supply, current government expenditure and real GDP in the current period on current inflation rate. They found that exchange rate depreciation, money supply and real gross domestic product are the main determinants of inflation in Nigeria, and that naira depreciation is positive, and has significant long - run effect on inflation in Nigeria. 
Akinbobola (2012) aims at providing quantitative analysis of the dynamics of money supply, exchange rate and inflation in Nigeria. The paper utilizes secondary data that were obtained from International Financial Statistics (IFS), of all variables investigated in the model. The sample covers quarterly data from 1986:01 to 2008:04. The model was estimated using Vector Error correction Mechanism (VECM). The empirical results shows that in the long run, money supply and exchange rate have significant inverse effects on inflationary pressure while real output growth and foreign prices changes have direct effects on inflationary pressure.

Zubair, okorie and Sanusi (2013) use the impulse response from an estimated structural autoregressive model of the inflation process to estimate the dynamic exchange rate pass-through to consumer prices for Nigeria, using quarterly data for the period 1986-2010. The results suggest that the exchange rate pass-through is incomplete, low and fairly slow. On impact, for instance, the elasticity of inflation to exchange rate changes is about 0.02 , and it takes eight quarters to reach its full-impact of only 0.26 . The variance decomposition analysis suggests that money supply has contributed more to Nigeria's inflation process relative to the exchange rate.

Ogundipe and Samuel (2013) state that the increasing over dependence of Nigerian economy on imports has necessitated the need to continually examine the effect of exchange rate shocks on consumer prices. They adopt a structural vector autoregressive to estimate the pass-through effect of exchange rate changes to consumer prices. Using the variance decomposition analysis, they found a substantially large exchange rate pass-through to inflation in Nigeria. Their findings show that exchange rate has been more important in explaining Nigeria's rising inflation phenomenon than the actual money supply.

The evidences from empirical literature on the exchange rate-inflation nexus have been mixed. This paper re-examines this issue in Nigeria. The paper contributes to the existing literature by including in the model for the study all the variables in the exchange rate channels in transmitting the impact of the monetary policy shock to consumer prices in Nigeria.

\section{Methodology}

\subsection{Theoretical Framework of the Study}

The quantity theory of money, the purchasing power parity and the money supply and demand framework show how the monetary policy shocks are transmitted to exchange rate. If the money stock rises without a corresponding increase in output, the additional money supply will simply bid up prices based on the quantity theory of money. As the price level rises, the exchange rate depreciates based on the purchasing power parity theory (Chamberlin and Yueh, 2006).

Given the demand for money, the rise in money supply causes a fall in domestic interest rate. The fall in domestic interest rate leads to an increase outflow of short-term finance from the country and a reduce inflow, as depositors seek to take advantage of relatively higher interest rate abroad. The supply of the domestic currency on the foreign exchange market rises and the demand falls. This causes a depreciation of the exchange rate (assuming the authorities allow it) [Sloman, 2006].

Thus, the monetary policy shocks may be transmitted to exchange rate through the price channel or interest rate channel or both. Consequently, this study adopts an approach in which these two channels of the transmission mechanism from money supply to exchange rate are hybridized. As such, the following specification of the VAR which reveals both simultaneity and interaction among the variables that are closely related to exchange rate and inflation can be stated as in equation (1).

\section{(CPI, MSP, INTR, EXCHR)}

Where: $\mathrm{CPI}=$ consumer price index representing the price level, MSP is money supply,

INTR $=$ interest rate and EXCHR is exchange rate.

In order to establish the transmission mechanism from exchange rate to consumer price index, this study complements the quantity theory of money, the purchasing power parity theory and the money supply and demand framework with the demand pull and cost push theories of inflation. On demand pull theory of inflation, the depreciation of the exchange rate causes a rise in demand for exports, since they are now cheaper for people abroad to buy. It also causes a fall in demand for imports, since they are now more expensive. The rise in exports and a fall in imports will lead to an increase in net exports and aggregate demand and will cause a multiplied rise in national income (sloman, 2006). But, in a short run, faster real growth may be associated with more rapid inflation. Often, this is because strong growth is the result of a rise in aggregate demand that causes real output to increase at the same time as it bids up prices (Tabi and Ondoa, 2011). Based on the demand pull theory of inflation, the net exports (NEXP) that is also closely related to exchange rate and inflation is included in the VAR model as specified in equation (2).

$$
\text { (CPI, MSP, INTR, EXCHR, NEXP) }
$$

In the system of floating exchange rates, exchange rates fluctuations can have a strong impact on the level of prices through the aggregate demand and aggregate supply. On the aggregate supply, depreciation (devaluation) of domestic currency can affect the price level directly through imported goods that domestic consumers pay. However, this condition occurs if the country is the recipient countries of international prices (international price taker). Non direct influence from the depreciation (devaluation) of currency against the price level of a country can be seen from the price of capital goods (intermediate goods) imported by the manufacturers as inputs. The weakening of exchange rate will cause the price of inputs more expensive, thus contributing to a higher cost of production. Manufacturers will certainly increase the cost to the price of goods that will be paid by consumers. As a result, 
the price level aggregate in the country increases or if it continues it will cause inflation (Achani, Fauzi and Abdullah, 2010). That is as exchange rate depreciates, the import price index increases and an increase in import price index will lead to an increase in producer price index. The increase in producer price index will lead to an increase in wholesale and retail price index and an increase in wholesale and retail price index will lead to an increase in consumer price index. Based on the cost-push theory of inflation, the import price index, producer price index, and wholesale and retail price index that are related to exchange rate and consumer price index are also included in the model as follows:

\section{(CPI, MSP, INTR, EXCHR, NEXP, IPI, PPI, WRPI)}

Where: IPI is import price index, PPI is producer price index, WRPI is wholesale and retail price index and all other variables are as previously defined.

\subsection{Model Specification}

This paper uses an eight variable vector autoregression (VAR) approach following McCarthy (1999) and Leigh and Rossi (2002) to examine the pass-through of exchange rate to consumer prices. The model is summarized in the reduced-form VAR:

$$
Y_{t}=\alpha_{0}+\sum_{i=1}^{n} \beta_{i} Y_{t-i}+U_{t}
$$

Where $Y_{t}$ is a $8 * 1$ vector of variables (CPI, MSP, INTR, EXCHR, NEXP, IPI, PPI, and WRPI,); $\beta_{\mathrm{i}}$ are coefficient matrices of size $8 \times 8$ and $u_{t}$ is the one-step ahead prediction error with variance-covariance matrix $\Sigma, \alpha_{0}$ is the intercept. The $t$ is time and $i$ is the lag length.

The VAR methodology deals with several endogenous variables together. But each endogenous variable is explained by its lagged, or past, values and the lagged values of all other endogenous variables in the model; usually, there are no exogenous variables in the model.

Since there are eight variables, the VAR technique is employed because it is very useful in dealing with multivariable causality. Forecasting is an important part of econometric analysis, for some people probably the most important. Vector autoregression has become quite popular method of forecasting economic variables.

As in any standard VAR model analysis, the way the variables enter the model is extremely important for the interpretation of the results. The most appropriate ordering is: CPI - MSP - INTR - EXCHR - NEXP - IPI - PPI - WRPI. The level of CPI has great influence on the amount of money supply. Money supply affects exchange rate indirectly through CPI channel. So, CPI or money supply should come first in the VAR. Money supply affects the exchange rate, possibly indirectly through the interest rate channel. The exchange rate may affect CPI directly. The exchange rate may also affect CPI indirectly through an increase in net exports and aggregate demand or through an increase in import price index, producer price index, and wholesale and retail price index.

\subsection{Estimation Method}

The VAR model is estimated using e-view 7.0. The time series properties of the data are analyzed using the Augmented Dickey-Fuller (ADF) unit root test of Dickey and Fuller (1979). Test of co-integration are carried out using the Johansen (1988) maximum likelihood procedure. The lag length is to be determined by the likelihood ratio (LR), final prediction error (FPE), Akaike information criteria (AIC), Schwarz information criteria (SC), and Hannan-Quinn information criteria (HQ). The VAR residual portmanteau tests for autocorrelations are used to verify the assumption of no autocorrelation. The inverse roots of autoregressive (AR) characteristic polynomial and VAR residual normality tests are used to verify whether the VAR model satisfy the stability and normality assumptions respectively.

\subsection{Data}

The empirical analysis is conducted using quarterly data. The time span covered is first quarter 2000 to fourth quarter 2013. The choice of 2000 as the base year is due to the fact that the data of import price index can only be obtained from that year.

The Consumer price index (CPI) of November 2009=100 is used as a measure of consumer prices. The quarterly data of narrow money supply $\left(\mathrm{M}_{1}\right)$ is chosen as the measure of money supply rather than broad money supply $\left(\mathrm{M}_{2}\right)$, as $\mathrm{M}_{2}$ includes foreign currency deposits and is therefore, more difficult for monetary authorities to control. The treasury bill rate (average discount rates on 3-month instruments) is the interest rate which is used to reflect changes in the Central Bank's behaviour. Exchange rate data are weighted average nominal exchange rate of the naira per unit of U.S. dollar. The U.S. dollar is used since it is the currency of Nigeria's major trading partner. The annual data of net exports are interpolated into quarterly data series using e-view. The quadratic-match average method of data processing is selected in interpolation. The import commodity price index of January $2007=100$ is used as import price index. An average implicit price deflator for agricultural and industrial goods and services is used as a measure of producer price index. Implicit price deflator for wholesale and retail trade is used as a measure of wholesale and retail price index.

The interest rate data are obtained from various publications of Central Bank of Nigeria (CBN) Statistical Bulletin. The data for other variables are obtained from CBN Statistical Bulletin (December, 2013 online edition: www.cbn.gov.ng). The data of all the variables are transformed to logarithms in order to be of the same standard. A plot of the logarithms of exchange rate and CPI is shown in Figure 1. From Figure 1, the naira/dollar exchange rate and CPI have shown a general upward trend for most of the periods. All the variables except interest rate are expected to have a positive relationship with CPI. 


\section{LEXCHR}
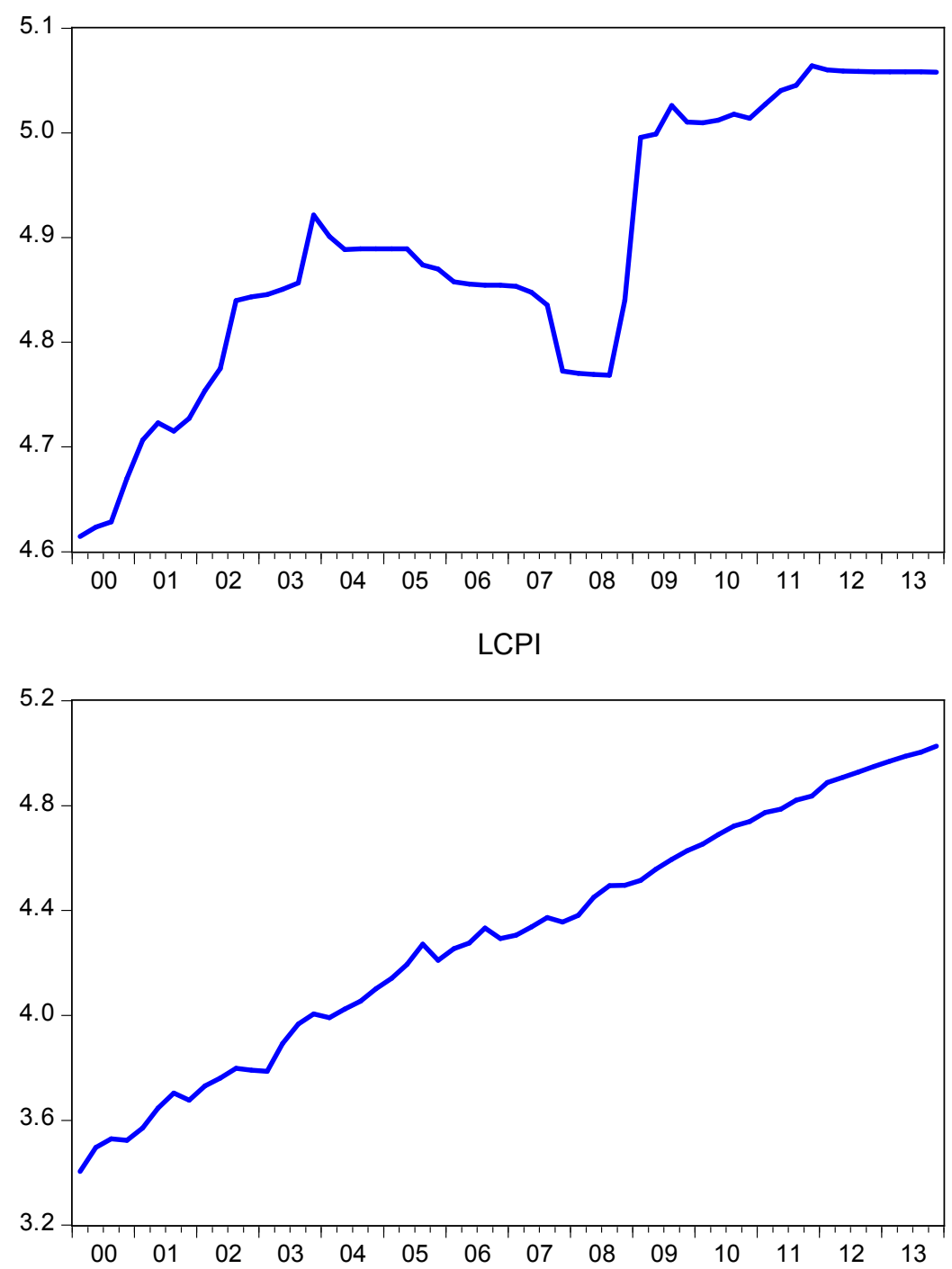

Figure 1. Logarithms of Exchange Rate and CPI.

\section{Results}

\subsection{Unit Root Test and Co-Integration Analysis}

The ADF test indicates that the logs of the variables are of different order of integration (zero, one and two) at $5 \%$ level of significance (Table 1). So, the co-integration test procedure is conducted. Table 2 reports the results of the Johansen test. Both the trace and maximum eigenvalue tests denote rejection of no co-integration at $5 \%$ level.

Table 1. Augmented Dickey-Fuller Test.

\begin{tabular}{|c|c|c|c|c|c|c|c|}
\hline \multirow{2}{*}{ Variables } & \multicolumn{2}{|l|}{ Levels } & \multicolumn{2}{|c|}{ First Differences } & \multicolumn{2}{|c|}{ Second Differences } & \multirow{2}{*}{ Order of Integration } \\
\hline & ADF-Statistic & Prob $^{*}$ & ADF-Statistic & Prob $^{*}$ & ADF-Statistic & Prob $^{*}$ & \\
\hline LMSP & -1.571 & 0.792 & -8.376 & 0.000 & - & - & $\mathrm{I}(1)$ \\
\hline LINTR & -2.879 & 0.117 & -7.991 & 0.000 & - & - & $\mathrm{I}(1)$ \\
\hline LEXCHR & -2.561 & 0.299 & -5.399 & 0.000 & - & - & $\mathrm{I}(1)$ \\
\hline LNEXP & -2.482 & 0.335 & -3.282 & 0.080 & -8.272 & 0.000 & $\mathrm{I}(2)$ \\
\hline LIPI & -3.694 & 0.031 & -9.509 & 0.000 & - & - & $\mathrm{I}(0)$ \\
\hline LPPI & -1.524 & 0.807 & -2.118 & 0.523 & -7.163 & 0.000 & $\mathrm{I}(2)$ \\
\hline LWRPI & -1.420 & 0.843 & -18.544 & 0.000 & - & - & I(1) \\
\hline LCPI & -3.381 & 0.065 & -7.405 & 0.000 & - & - & I(1) \\
\hline
\end{tabular}

Test critical values: $1 \%-4.166$

$5 \%-3.059$

$10 \%-3.184$

*MacKinnon (1996) one sided $\rho$-values

Source: Author's Computation. 
Table 2. Johansen Test for Co-integration Vectors.

\begin{tabular}{|c|c|c|c|c|c|c|}
\hline \multirow{2}{*}{ Hypothesized No. of CE(s) } & \multicolumn{3}{|l|}{ Trace } & \multicolumn{3}{|l|}{ Maximum Eigenvalue } \\
\hline & Trace Statistic & 0.05 Critical Value & Prob** & Max-Eigen Statistic & 0.05 critical value & Prob** \\
\hline None* & 393.925 & 159.530 & 0.000 & 139.646 & 52.363 & 0.000 \\
\hline At most $1 *$ & 254.279 & 125.615 & 0.000 & 77.574 & 46.231 & 0.000 \\
\hline At most $2 *$ & 176.704 & 95.754 & 0.000 & 49.041 & 40.078 & 0.004 \\
\hline At most $3^{*}$ & 127.663 & 69.819 & 0.000 & 45.499 & 33.877 & 0.001 \\
\hline At most $4 *$ & 82.164 & 47.856 & 0.000 & 33.384 & 27.584 & 0.008 \\
\hline At most $5^{*}$ & 48.780 & 29.797 & 0.000 & 22.253 & 21.132 & 0.035 \\
\hline At most $6^{*}$ & 26.526 & 15.495 & 0.001 & 19.490 & 14.265 & 0.007 \\
\hline At most $7 *$ & 7.036 & 3.841 & 0.008 & 7.036 & 3.841 & 0.008 \\
\hline
\end{tabular}

*denotes rejection of the hypothesis at the 0.05 level

**MacKinnon-Hang-Michelis (1999) $\rho$-values

Source: Author's Computation.

Table 3. VAR Lag Order Selection.

\begin{tabular}{llllll}
\hline Lag & LR & FPE & AIC & SC & HQ \\
\hline 0 & NA & $5.36 \mathrm{e}-12$ & -3.250 & -2.958 & -3.137 \\
1 & 620.585 & $7.78 \mathrm{e}-17$ & -14.414 & $-11.817^{*}$ & -13.397 \\
2 & 127.996 & $3.08 \mathrm{e}-17$ & -15.494 & -10.485 & -13.562 \\
3 & 107.043 & $1.25 \mathrm{e}-17$ & -16.866 & -9.431 & -14.007 \\
4 & $1.64 \mathrm{e}-18^{*}$ & $-20.081^{*}$ & -10.175 & $-16.283^{*}$ \\
\hline
\end{tabular}

*indicates lag order selected by the criterion

Source: Author's Computation.

\subsection{Vector Autoregression (VAR) Estimation}

The results of the lag length selection presented in table 3 reveals that all the five criteria except Schwarz information criterion (SC) indicate 4 lags as the optimal model. Since the logs of the variables are co-integrated, the VAR is estimated in log level with 4 lags based on Akaike information criterion (AIC).

\subsection{Diagnostic Tests}

A battery of tests was conducted to evaluate the statistical properties of the model. The VAR residual portmanteau tests for autocorrelations show that the residuals of the VAR model are not correlated. The inverse roots of autoregressive (AR) characteristic polynomial show that at least, one root is equal to 1 which indicates that the VAR model is unstable. However, the VAR model satisfies the normality condition. Having satisfied to some extent the statistical prerequisites, impulse response and variance decomposition are used to examine the pass-through effects of exchange rate on consumer prices.

\subsection{Impulse Response Analysis}

Figure 2 presents the response of CPI to variables shocks. The response of LCPI to log of exchange rate [Figure 2(d)] ranges from -0.002 to 0.010 during the ten periods. It is positive indicating a positive relationship between exchange rate and CPI. The result shows that exchange rate depreciation leads to an increase in the price level through a decrease in the consumer goods and services that are supplied from foreign countries.

Figure 2 shows that the theoretical expectations of all the explanatory variables, except wholesale and retail price index are met. The positive and significant response of LCPI to log of money supply [Figure 2(b)] is based on the proposition that inflation is always and everywhere a monetary phenomenon. The negative response of LCPI to log of interest rate [Figure 2(c) is based on the premise that an increase in interest rate leads to a fall in the price level because higher interest rate can reduce aggregate demand by discouraging borrowing by households and firms. The positive response of LCPI to log of net exports [Figure 2(e)] is because an increase in net exports leads to an increase in aggregate demand and in monetarist view, an increase in aggregate demand causes a rise in real output or price or both. The positive response of LCPI to log of import price index [Figure 2(f)] is based on the fact that an increase in import price index affects the price level directly through imported goods that domestic consumers pay. The positive response of LCPI to log of producer price index [Figure 2(g)] is based on the fact that the increase in producer price index leads to a higher cost of production and manufacturers add the increase in the cost of production to the price of goods that are paid by consumers. The justification for the negative response of LCPI to log of wholesale and retail price index [Figure 2(h)] is that many wholesalers and retailers will simply reduce their mark-ups and profit margins in order to keep the price stable in a perfectly competitive 
market when the exchange rate is depreciating. The positive and significant response of LCPI to its own shocks [Figure 2(a)] indicates that inflation process in Nigeria has significant inertia, which implies that inflation expectations are largely determined by past events.

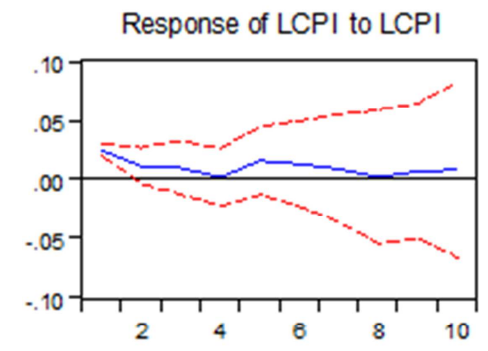

(a)

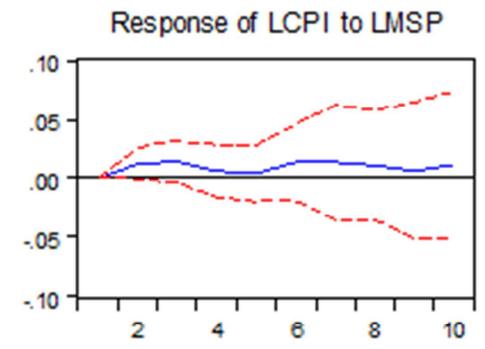

(b)

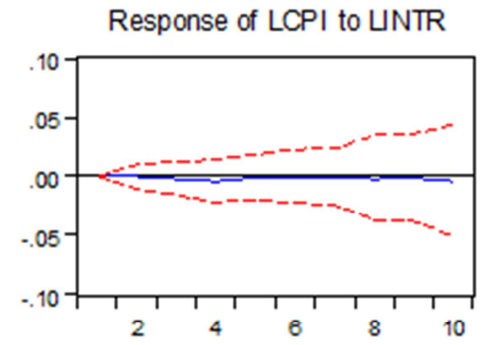

(c)
Response of LCPI to LEXCHR

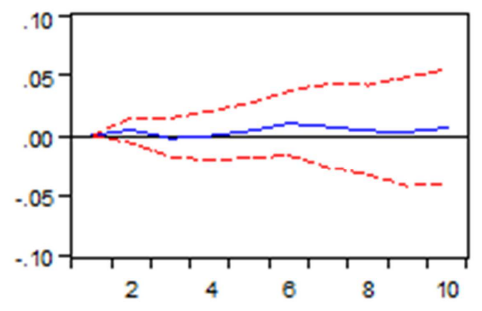

(d)

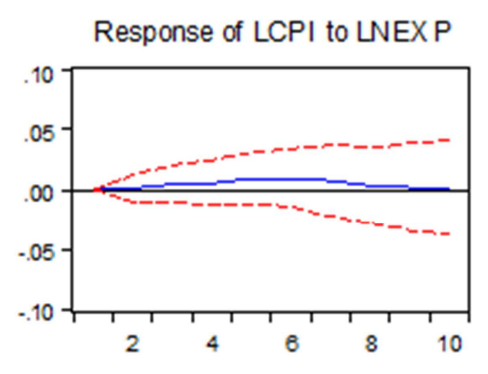

(e)

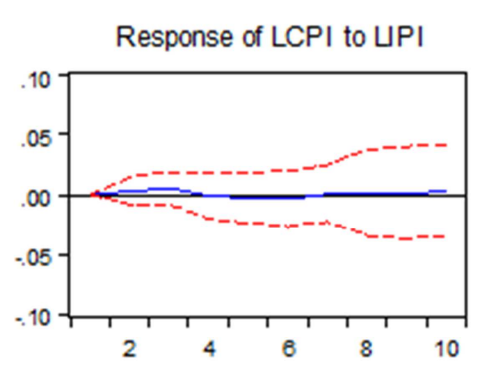

(f)

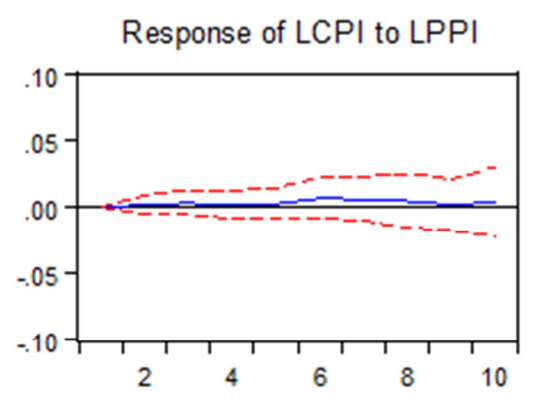

(g)

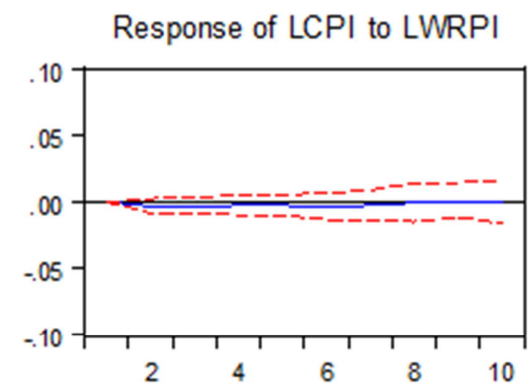

(h)

Figure 2. Response of Consumer Price Index to Variables Shocks.

\subsection{Variance Decomposition}

Figure 3 displays the variance decomposition of CPI to variables shocks. The variance decomposition of LCPI to log of exchange rate ranges from zero percent to 7.875 percent during the ten periods. The contribution of exchange rate to the variation of CPI is statistically insignificant and this suggests a low ERPT in Nigeria. Mishkin (2008) argues that in the context of a stable and predictable monetary policy environment, nominal shocks play a significantly reduced role in determining fluctuations in consumer prices; thus a stable monetary policy eliminates an important potential source of exchange rate pass-through into consumer prices. Taylor (2000) argues that the establishment of a strong nominal anchor in many countries in recent years is responsible for a low pass-through of exchange rate depreciation to inflation.

Figure 3 shows that the increases in CPI are mainly due to its own shocks and the increase in money supply in the long run. Because inflation has the characteristic of inertia, current low inflation will lead to low inflation in the future and high inflation normally predicts incoming high inflation in the future. 


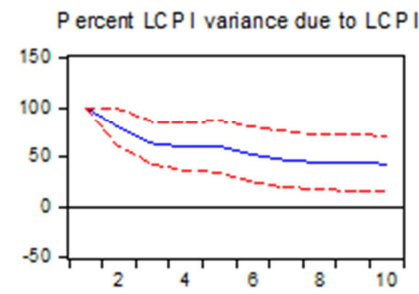

(a)

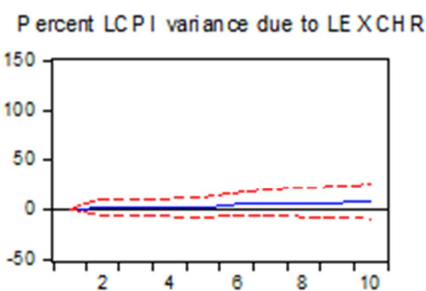

(d)

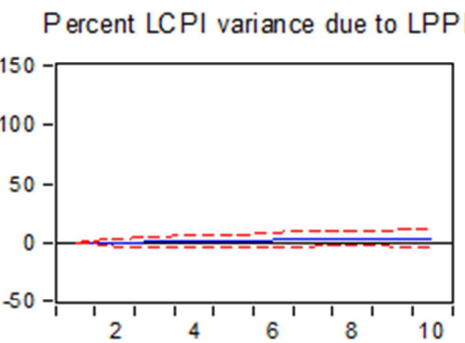

(g)

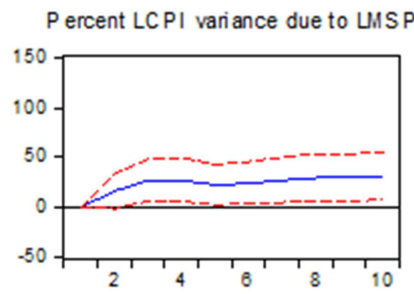

(b)

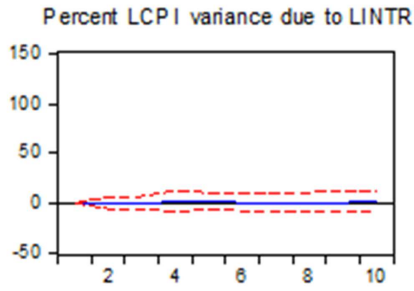

(c)

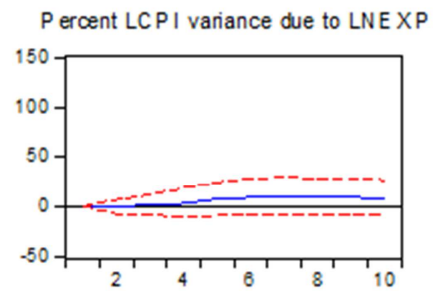

(e)

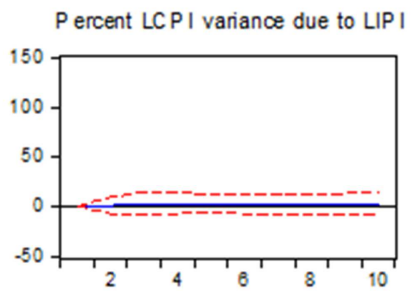

(f)

Figure 3. Variance Decomposition of Consumer Price Index to Variables Shocks.

\section{Conclusions}

The exchange rate depreciation has a positive and insignificant effect on consumer prices in Nigeria, and the increase in consumer prices are mainly due to its own shocks and the increase in money supply in the long run. The consumer prices will fall if money supply is reduced and once consumer prices are stabilized at low levels the inflationary impacts of exchange rate depreciations will also be lower. This implies that the policy makers should put in more efforts at achieving monetary stability. A stable monetary policy with a low inflationary environment will lessen the pressure of exchange rate changes on consumer prices. So, the CBN should be less concern with the inflation impact of exchange rate shocks and focus fully on other objectives such as growth and export competitiveness in designing exchange rate policy.

\section{Strengths and Weaknesses of the Work}

A supply shock, demand shock and external shock together with domestic price indices are employed in a recursive VAR framework. A VAR model is useful in allowing for endogenous interactions between the exchange rate and other macroeconomic variables. With the use of VAR model, this paper was able to determine the pass-through relationship from exchange rate to consumer prices in Nigeria. However, a reverse causation-impact of domestic prices on the exchange rate may exist.

The first weakness of this paper is that the data for wholesale and retail price indices are lumped together. The unavailability of a separate data for wholesale price index and retail price index could not enable this paper to determine the effect of each of these variables on consumer prices in Nigeria separately. This paper is also weak because the channel through which exchange rate changes is transmitted to consumer prices in Nigeria has not been established.

\section{Suggestions for Further Studies}

Since forecasting is in the heart of economic models, such forecasts may be as robust as should be expected by its 
advocates if the necessary data are made available to implement them. The officially designated data collection and processing institutions in Nigeria should be able to collect separate data on wholesale and retail price indices. If this is done, then, this paper can be improved if the effects of the wholesale price index and retail price index on consumer prices are estimated separately.

There are three channels through which exchange rate depreciations are transmitted to consumer prices. First, exchange rate depreciation maybe transmitted directly to consumer prices through a decrease in the final goods and services that are supplied from foreign countries. Second, exchange rate depreciation may be transmitted indirectly to consumer prices through an increase in the price of capital goods imported by the manufacturers as inputs. Third, exchange rate depreciation may be transmitted to consumer prices through an increase in net exports and aggregate demand. This paper will be improved if the channel through which exchange rate depreciation is transmitted to consumer prices in Nigeria is established.

\section{References}

[1] Achsani, N. A.; A. J. F.A. Fauzi and P. Abdullah (2010), "The Relationship between Inflation and Real Exchange Rate: Comparative Study between ASEAN+3, the EU and North America", European Journal of Economics, Finance and Administrative Sciences - Issue 18, 69-76.

[2] Akinbobola T. O. (2012), "The Dynamics of Money Supply, Exchange Rate and Inflation in Nigeria", Journal of Applied Finance and Banking, Vol. 2, no. 4, 117-141, Scienpress Ltd.

[3] Chamberlin, G. and L. Yueh (2006), Macroeconomics, UK: Thompson Learning.

[4] Chowdhury, M. I. and S. F. Siddique (2006), "Exchange Rate Pass-Through in Bangladesh", Policy Analysis Unit (PAU) Working Paper Series No.WP0607, April.

[5] Dickey, D. A. and W. A. Fuller (1979), "Distribution of the Estimators for Autoregressive Time Series with a Unit Root, Journal of the American Statistical Association, 74, p. 427-431.

[6] Frimpong, S. and A. M. Adam (2010), "Exchange Rate Pass-Through in Ghana", International Business Research, Vol. 3, No. 2, 186-192, April.

[7] Fullerton, T. M. Jr. and S. I. Ikhide (1998), "An Econometric Analysis of the Nigerian Consumer Price Index", Journal of Economics, Volume 24, Number 2, Pages 1-15.

[8] Goldberg, P. and M. Knetter (1997), "Goods Prices and Exchange Rates: What Have We Learned?", Journal of Economic Literature, Vol. 35, No. 3, September, pp. 1243-1272.
[9] Imimole, B. and A. Enoma (2011), "Exchange Rate Depreciation and Inflation in Nigeria(1986-2008)", Business and Economic Journal, Volume 2011:BEJ-28, Pp 1-12.

[10] Johansen, S. (1988), "Statistical Analysis of Co-integrating Vectors", Journal of Economic Dynamics and Control, 12, Pp. 231-54.

[11] Justel, S. and A. Sansone(2015), "Exchange Rate Pass-Through to Prices: VAR Evidence for Chile", Working papers of the Central Bank of Chile, No.747, February.

[12] Kahn, G. A. (1987), "DollarDepreciation and Inflation", Federal Reserve Bank of Kansas City Economic Review, Vol. 72, No. 9, November, pp. 32-49.

[13] Leigh, D. and M. Rossi (2002), "Exchange Rate Pass-Through in Turkey", IMF Working Paper, WP/02/2004.

[14] McCarthy, J. (1999), "Pass-Through of Exchange Rates and Import Prices to Domestic Inflation in Some Industrialized Economies", BIS Working paper No. 79.

[15] Menon, J. (1995), "Exchange Rate Pass-Through", Journal of Economic Surveys, Vol. 9, No. 2, June, pp. 197-231.

[16] Minh, V. V. (2009), "Exchange Rate Pass-Through and its Implications for Inflation in Vietnam", Vietnam Development Forum Working Paper Series No.0902, 1-66, April.

[17] Mirdala, R. (2014), "Exchange Rate Pass-Through to Domestic Prices under Different Exchange Rate Regimes", Williams Davidson Institute Working papers, Number 1070, January, University of Michigan.

[18] Mishkin, F. (2008), "Exchange Rate Pass-Through and Monetary Policy”, NBER Working Paper 13889.

[19] Mohammed, K. S. et al (2015), "Exchange Rate Pass-Through In Algeria", Mediterranean Journal of Social Sciences, Vol. 6, No. 2, March, MCSER Publishing, Rome-Italy.

[20] Ogundipe, A. A. and E. Samuel (2013), "Exchange Rate Pass-Through to Consumer Prices in Nigeria", Scientific Papers: Journal of Business Management and Applied Economics, Vol. II, Issue 4, July.

[21] Sloman, J. (2006), Economics, Sixth Edition, UK: Pearson Education Limited.

[22] Tabi, H. N. and H. A. Ondoa (2011), "Inflation, Money and Economic Growth in Cameroon", International Journal of Financial Research, Vol. 2, No. 1, March, www.sciedu.ca/ijfr.

[23] Taylor, J. B. (2000), "Low Inflation, Pass-Through and the Pricing power of Firms", European Economic Review, 44:1389-1408.

[24] Zubair, A.; G. Okorie and A. R. Sanusi (2013), "Exchange Rate Pass-Through to Domestic Prices in Nigeria: An Empirical Investigation", Economic and Financial Review, Volume 51, Number 1, March. 